\title{
IMPACT OF RAINFALL AND TEMPERATURE ON TEA PRODUCTION IN
}

\section{UNDIVIDED SIVASAGAR DISTRICT}

\author{
SUPRIYASONOWAL ${ }^{1}$, I. P. SAHEWALLA ${ }^{2}$, R. P. BHUYAN ${ }^{3}$, J. P. HAZARIKA ${ }^{4}$, \\ SHYAMAL KUMAR PHUKON ${ }^{5} \&$ MILONJYOTI KONWAR ${ }^{6}$ \\ 1, 2, 3,5 Department of Tea Husbandry and Technology, Assam Agricultural University, Jorhat, Assam, India \\ ${ }^{4}$ Department of Agril. Economics \& Farm Management, Assam Agricultural University, Jorhat, Assam, India \\ ${ }^{6}$ Department of Agronomy, Assam Agricultural University, Jorhat, Assam, India
}

\begin{abstract}
Climate change is one of the barriers in tea production. In Assam region tea production has decline in recent year, although the area under has been risen. Taking this into consideration the impact of climate change on tea production was conducted in undivided Sivasagar district (viz. Sivasagar, Jorhat and Golaghat). To select the samples for the study, a random sampling technique was followed. A sample of 15 tea estates were selected from undivided Sivasagar district and five tea estates were selected from each district. Keeping in view both primary and secondary data have been collected and used for the study from published and unpublished sources for the duration of 1986-2015. Results revealed that the variability of different climatic parameters such as rainfall, maximum temperature were higher in the period II in comparison with the period I. In case of the climatic parameters minimum temperature was less variable in the period II. The climatic parameters, maximum temperature was found to have significant positive effect on yield of tea in Sivasagar district, but the minimum temperature had negative effect without significance in the period however, in case of period II, there was no significant effect of climatic parameters on yield of tea.

KEYWORDS: Climate Change, Rainfall, Tea \& Temperature
\end{abstract}

Received: Dec 09, 2017; Accepted: Dec 29, 2017; Published: Jan 10, 2018; Paper Id.: IJASRFEB20188

\section{INTRODUCTION}

The tea plant [Camellia sinensis (L.), O. kunze] is one of the most important beverage evergreen crop in the world which is basically a rain fed crop. India is the $2^{\text {nd }}$ largest producer and consumer\& $4^{\text {th }}$ largest exporter of tea with 25 per cent share in global production and 12 per cent share in world tea exports. Gourdjiet al. (2013) reported that climate change is an internationally recognized problem that is having impacts across the planet. It is problematic as it is causing shifts in the normal climatic conditions such as rainfall and temperature, which in turn is placing pressure on the planet's natural environmentIn particular climate change is having a significant impact on agriculture, especially those crops that are dependent on consistent climatic conditions.

Tea supports livelihoods across the humid regions of south and south-east Asia and East Africa. The ecophysiology of tea plants is closely linked to external environmental and climatic factors (precipitation, temperature) and any adversity in these conditions can significantly impact yield, revenue and livelihood security. The relationship between tea yield and climate factors impact the key physiological and developmental processes that determine the yield of tea. 
The impact of climate change has stood as a barrier in tea production which is shown by reduction in the rainfall in the last 90 years by around 200 millimeters. Considering all thesefactors it is felt necessary to study the effects of tea production in relation to climatic parameters viz. temperature and rainfall in undivided Sivasagar district.

\section{METHODOLOGY}

The study was conducted in undivided Sivasagar district of Assam. Undivided Sivasagar district is composed of three district viz. Sivasagar district, Jorhat district and Golaghat district. Sivasagar district is located in between $26.45^{\circ} \mathrm{N}$ and $27.15^{\circ} \mathrm{N}$ latitudes and $94.25^{\circ} \mathrm{E}$ and $95.25^{\circ} \mathrm{E}$ longitudes. This district is bounded by the Brahmaputra River on the north, Nagaland on the south and the Jhanji River on the west. Jorhat district is located at northern latitude of $26.75^{\circ} \mathrm{N}$ and eastern longitudes of $94.22^{\circ} \mathrm{E}$. It is located in the central part of Brahmaputra Valley with an area of $2851 \mathrm{sq} \mathrm{km}$. This district is bounded by Lakhimpur district on north, Nagaland state on south, Sivasagar on the east and Golaghat on the west. Golaghat district is located at northern latitudes of $26.52^{\circ} \mathrm{N}$ and eastern longitudes of $93.97^{0} \mathrm{E}$. It is surrounded by the river Brahmaputra to the north, the state of Nagaland to the south, Jorhat district to the east and KarbiAnglong and Nagaon district to the west. Two types of data are collected such as primary and secondary data which are detailed below.

Primary data on areaand production were selected from Sivasagar district, Jorhat district and Golaghat district due to long term availability and closer representativeness of the entire study area. Aggregate levels of data were collected from the 15 tea estates of the three districts for the period of 1986-2015. Secondary data relating to the long term weather data which were collected from meteorological observatories of Assam Agricultural University and Tocklai Tea Research Institute, Jorhat for the period of 1986-2015. The mean data of these two centres have been calculated. A sample of 15 tea estates were selected from undivided Sivasagar district and five tea estates were selected from each district.

Climatic parameters such as temperature and rainfall are collected and analyzed with appropriate methods as required such as Cobb- Douglas's production function for study the effect of climatic factors on tea productivity.

\section{RESULTS AND DISCUSSSIONS}

\section{Rainfall Variability}

In Table 1, the average rainfall of Sivasagar, Jorhat and Golaghat have been shown. The average annual rainfall of Sivasagar district during Period I was $2125.94 \mathrm{~mm}$ with a standard deviation (SD) of $153.29 \mathrm{~mm}$ and coefficient of variation $(\mathrm{CV})$ of 7.21 per cent with a minimum rainfall of $1905.88 \mathrm{~mm}$ to a maximum rainfall of $2386.04 \mathrm{~mm}$. During the Period II, the average rainfall was $2198.86 \mathrm{~mm}$ with a standard deviation (SD) of $173.42 \mathrm{~mm}$ and coefficient of variation (CV) of 7.88 per cent. From the table, it was observed that the annual variability of rainfall in Sivasagar district during the Period II was higher (CV 7.88 per cent) in comparison to Period I with a coefficient of variation $(\mathrm{CV})$ of 7.21 per cent.

In case of Jorhat district, the mean annual rainfall was found to be higher (1862.02 mm) in the Period I than the Period II (1802.60 mm). In Period II the standard deviation (SD) $(276.12 \mathrm{~mm})$ and the coefficient of variation $(\mathrm{CV})(15.31$ per cent) was higher than the Period I which were $225.59 \mathrm{~mm}$ and 12.11 per cent respectively, and it was observed that minimum rainfall $(1221.80 \mathrm{~mm})$ was lower in the Period II and the maximum rainfall $(2277.30 \mathrm{~mm})$ was higher in the same period in comparison to Period I, which was the main reason for higher variability in rainfall during the Period II.

Also the descriptive statistics of average rainfall in Golaghat district during the Period I and II. It was observed that the average rainfall was higher in the Period I $(1432.60 \mathrm{~mm})$ than that of Period II $(1317.13 \mathrm{~mm})$. In the Period I, the 
maximum rainfall was higher, but in Period II the minimum rainfall was lower in the district. It was observed that the annual variability in rainfall in the Golaghat district was higher (CV 15.49 per cent) than the Period I (CV 12.01 per cent). The standard deviation (SD) in the Period II with $204.12 \mathrm{~mm}$ was found to be much higher than the Period I with standard deviation $172.07 \mathrm{~mm}$. All these were in line with Khan et al. (2000).

Table 1: Descriptive Statistics of Average Annual Rainfall (mm) for Sivasagar, Jorhat and Golaghat District during Period I and Period II

\begin{tabular}{|c|c|c|c|c|c|}
\hline Period & Average & Minimum & Maximum & SD & CV (\%) \\
\hline \multicolumn{7}{|c|}{ Sivasagar District } \\
\hline I & 2125.94 & 1905.38 & 2386.04 & 153.29 & 7.21 \\
\hline II & 2198.86 & 1847.52 & 2595.82 & 173.42 & 7.88 \\
\hline \multicolumn{7}{|c|}{ Jorhat District } \\
\hline I & 1862.02 & 1530.80 & 2143.40 & 225.59 & 12.11 \\
\hline II & 1802.60 & 1221.80 & 2277.30 & 276.12 & 15.31 \\
\hline \multicolumn{7}{|c|}{ Golaghat District } \\
\hline I & 1432.60 & 1226.58 & 1719.91 & 172.07 & 12.01 \\
\hline II & 1317.13 & 1051.00 & 1657.00 & 204.12 & 15.49 \\
\hline
\end{tabular}

\section{Temperature Variabilty}

From the figure 1, it was observed that the maximum and minimum temperature of Sivasagar district did not vary too much during the study period from 1986 to 2015.

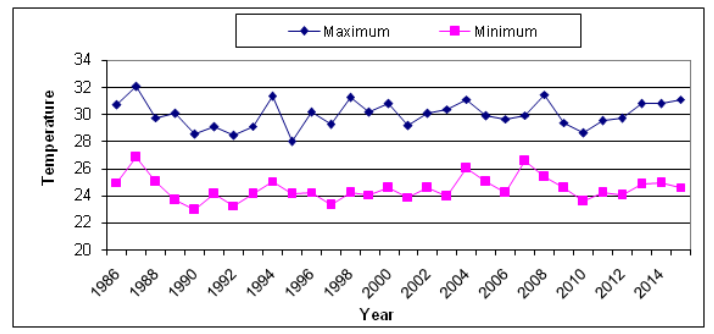

Figure 1: Average Annual Temperature $\left({ }^{0} \mathrm{C}\right)$ in Sivasagar District during 1986-2015

As discussed above, the Figure 2 verified that the variation in the maximum and minimum temperature varied less during the study period from 1986 to 2015.

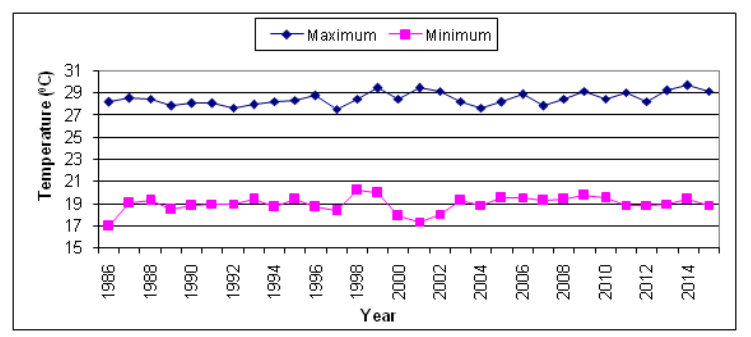

Figure 2: Average Annual Temperature $\left({ }^{0} \mathrm{C}\right)$ in Jorhat District during 1986-2015

From the Figure 3, it was observed that both the maximum and minimum temperature were decreasing over the period of study in Golaghat districtwith maximum temperature declining from $33{ }^{0} \mathrm{C}$ in 1986 to about $29{ }^{0} \mathrm{C}$ in 2015 and in minimum temperature decreasing from about $27{ }^{\circ} \mathrm{C}$ in 1986 to $19{ }^{\circ} \mathrm{C}$ in 2015 . 


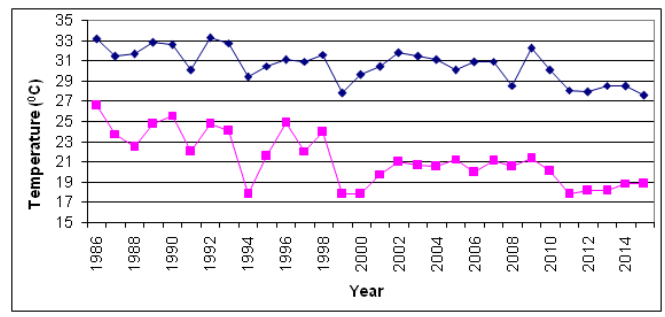

Figure 3: Average Annual Temperature $\left({ }^{0} \mathrm{C}\right)$ in Golaghat District during 1986-2015

The variability of tea production in Sivasagar, Jorhat and Golaghat district is presented in the Table 2. The average annual production for Sivasagar district during the Period II (988.28 ton) was higher than the Period I (874.98 ton). The standard deviation (SD) was higher with 52.13 ton in the Period I as compared to 47.34 ton in Period II and the variability was also found to be higher in Period I (5.95 per cent) than the Period II (4.79 per cent). In case of Jorhat, the average annual production during Period I was 943.17 ton with a standard deviation (SD) of 65.35 ton and coefficient of variation $(\mathrm{CV})$ of 6.93 per cent and it varied from 850.40 ton to 1072.92 ton. During Period II, the average annual production was 989.07 ton with standard deviation (SD) of 90.45 ton and coefficient of variation (CV) of 9.14 per cent. It was observed that the variability of production was higher in Period II as compared to Period I. However, it was observed that the coefficient of variation (CV) was highest in Golaghat district (8.07 per cent) during the Period I and it was found in highest in Jorhat district (9.14 per cent) during Period II. The coefficient of variation did not differ much for Sivasagar district during the two periods of the study. Similar trends were found by Ahmed et al. (2010).

Table 2: Descriptive Statistics of Average Annual Production (Ton) for Sivasagar, Jorhat and Golaghat District

\begin{tabular}{|c|c|c|c|c|c|}
\hline Period & Average & Minimum & Maximum & SD & CV (\%) \\
\hline \multicolumn{7}{|c|}{ Sivasagar District } \\
\hline I & 874.98 & 813.47 & 986.10 & 52.13 & 5.95 \\
\hline II & 988.28 & 931.64 & 1070.07 & 47.34 & 4.79 \\
\hline \multicolumn{7}{|c|}{ Jorhat District } \\
\hline I & 943.17 & 850.40 & 1072.92 & 65.35 & 6.93 \\
\hline II & 989.07 & 856.06 & 1131.53 & 90.45 & 9.14 \\
\hline \multicolumn{7}{|c|}{ Golaghat District } \\
\hline I & 491.46 & 427.15 & 549.15 & 39.68 & 8.07 \\
\hline II & 532.85 & 482.63 & 563.92 & 31.20 & 5.85 \\
\hline
\end{tabular}

\section{CONCLUSIONS}

Climatic parameters variation effects tea production. The variability of different climatic parameters such as rainfall and temperature were higher in the Period II in comparison with the Period I. In case of the climatic parameters minimum temperature, relative humidity was less variable in the Period II. The variability in production in Sivasagar and Golaghat district were lower variability in the Period II and Jorhat district was highest variability during the corresponding period. Maximum temperature was found to have significant positive effect on yield of tea in Sivasagar district, but the minimum temperature and evaporation had negative effect without significance in the Period I. In case of Period II, there was no significant effect of climatic parameters on production of tea in Jorhat district maximum temperature was found to have significant effect on production of tea in both the periods. From all these we can say that climatic variation resulted in tea production fluctuation. 


\section{REFERENCES}

1. Ahmed, S.,Unachukwu, U., Stepp, J. R., Peters, C. M., Long, C., Kennelly, E. 2010. Pu-erh tea tasting in Yunnan, China: correlation of drinkers' perceptions to phytochemistry. J. Ethnopharmacol.132(1): 176-185

2. Gourdji, S. M., Mathews, K. L., Reynolds, M.,Crossa, J., Lobell, D. B. 2013. An assessment of wheat yield sensitivity and breeding gains in hot environments. Proceedings of the Royal Society of London B: Biological Sciences. 280(1752): 20122190.

3. Khan, T. M. A., Singh, O. P., SazedurRahman, M. D. 2000. Recent sea level and sea surface temperature trends along the Bangladesh coast in relation to the frequency of intense cyclones. Marine Geodesy. 23: 103-116. 
